\title{
COVID-19: the Austrian Experience
}

\section{Florian Heger ${ }^{1,2}$, Hanns Moshammer ${ }^{2,3}$}

${ }^{1}$ Austrian Agency for Health and Food Safety, Vienna, Austria. ${ }^{2}$ Medical University of Vienna, Department of Environmental Health, Vienna, Austria. ${ }^{3}$ Medical University of Karakalpakstan, Nukus, Uzbekistan, Nukus, Uzbekistan.

\begin{abstract}
This short paper reports on the Austrian experiences with the Corona pandemic in the first quarter of 2020. In the beginning Austrian experts neglected the threat but a cluster in a skiing resort including international visitors served as a wake-up call and quickly after that strict and successful measures were applied. The paper proceeds describing the development of SARS-CoV-2 PCR testing and upgrading of testing facilities in Austria. The Austrian Agency for Health \& Food Safety (AGES) played a leading role in this process. International cooperation and information exchange were fundamental to the successful implementation of specific and sensitive laboratory methods.
\end{abstract}

Keywords: COVID-19- SARS-CoV-2- Austria- PCR tests- Policies

Asian Pac Environ Cancer, 3 (Suppl 1), 3-4

\section{Public health impact}

COVID-19 is an infectious disease caused by a novel Corona virus that first appeared in China late in 2019 [1] and reached pandemic distribution early in 2020 [2]. The first major outbreak in Europe occurred in Northern Italy from where it spread to neighboring countries, notably to Austria, where skiing resorts served as a main transmission hub. Also as a reaction on international complaints the Austrian government soon afterwards introduced strict measures curbing the spread of the virus. On March $16^{\text {th }}$ a very strict lock-down was introduced all over Austria [3]. These public health measures were strongly criticized then from several sides.

Using publicly available data the efficiency of governmental measures was assessed. Assuming an average incubation period of one week and an average duration of infectivity of 10 days the basic reproduction number was estimated. One week after the introduction of strict measures, the peak in daily new cases was reached, while the reproduction number already dropped immediately after the measures were implemented. The crude estimates tended to overestimate the reproduction number in the early phase. Publicly available data provide a first estimate about the effectiveness of public health measures [3]. However, more data are needed for an unbiased assessment.
Submission Date: 06/12/2020Ａcceptance Date: 07/07/2020

The overall effects of these public health measures need further evaluation. The adverse side effects of the lock-down include an economic and psychological burden for the society as a whole and for individuals. Social distancing measures and wide-spread and likely exaggerated fears also lead to dangerous behaviours, e.g. when people in urgent need of care did not dare to visit doctors or hospitals. Beneficial side-effects include a reduction also in other respiratory infections, reduced occupational stress for many jobs, and improved air quality [4].

As opposed to other European countries Austria did not observe an increased overall mortality rate during the epidemic. Long-term effects on health and mortality will become subject to investigation later only.

\section{PCR testing}

One cornerstone of the successful management of a pandemic or epidemic situation is thorough surveillance and the implication of a reliable testing procedure. In the case of COVID-19 a PCR testing scheme was developed quickly thanks to international cooperation:

On December 312019 WHO China country office was informed about a cluster of viral pneumonia cases of unknown cause in Wuhan City in Chinese Hubei Province. Authorities quickly pointed out a connection to a nearby

\footnotetext{
Corresponding Author:

Dr. Hanns Moshammer

Medical University of Vienna, Department of Environmental Health, Vienna, Austria. Medical University of Karakalpakstan, Nukus, Uzbekistan,

Nukus, Uzbekistan.

Email: hanns.moshammer@meduniwien.ac.at
} 
seafood market. Via metagenomic RNA sequencing researchers identified a previously unknown coronavirus as the causative agent. Short after, genome sequencing revealed an $85 \%$ sequence identity with a known SARS-like coronavirus found in bats [5]. Genome sequences were deposited in an open access database. On January 13 the National Conciliar Laboratory for Coronaviruses hosted at the Charité in Berlin released a protocol [6] for the diagnostic detection of 2019-nCoV (now known as SARS-CoV-2) by real-time RT-PCR, based on E-gene and RdRp-gene, which WHO published in its interim guidance for laboratory testing for COVID-19 in suspected human cases.

The Austrian Agency for Health \& Food Safety (AGES), on behalf of the Republic of Austria, started testing at two of its institutes for SARS-CoV-2 on February 11 with first positive test results on February 25. During the following weeks test numbers from both institutes combined rose from two tests a day to up to 1058 tests a day just two months later.

The main goal was to build up a constant testing capacity for the whole country until hospital laboratories and private laboratories had built up a testing infrastructure and were ready to conduct testing on their own.

At the beginning of March firsts public hospitals and later also private laboratories started testing for SARS-CoV-2, raising total testing numbers in Austria up to an average of 1.636 tests a day in March and 6.469 tests a day in April.

In conclusion AGES implemented and maximized a new testing capacity for SARS-CoV-2 within a few weeks after outbreak, completing up to $40 \%$ of all tests conducted in Austria at that point and ensuring a constant testing possibility at the critical first weeks of the epidemic.

\section{References}

1. Tan W, , Zhao X, Ma X, Wang W, Niu P, Xu W, F. Gao G, Wu $\mathrm{G}$, . A Novel Coronavirus Genome Identified in a Cluster of Pneumonia Cases - Wuhan, China 2019-2020. China CDC Weekly. 2020;2(4):61-62. https://doi.org/10.46234/ ccdew2020.017

2. WHO Director-General's Opening Remarks at the Media Briefing on COVID-19-11 March 2020. Available online: https:/www.who.int/dg/speeches/detail/who-directorgeneral-s-opening-remarks-at-the-media-briefing-on-covid19---11-march-2020 (accessed on 8 April 2020)..

3. Moshammer H, Poteser M, Lemmerer K, Wallner P, Hutter H. Time Course of COVID-19 Cases in Austria. International Journal of Environmental Research and Public Health. 2020 05 07;17(9):3270. https://doi.org/10.3390/ijerph17093270

4. Yari S, Moshammer H. The Effect of Ambient Air Pollution on Severity of COVID19: Hospitalisation and Death. Asian Pacific Journal of Environment and Cancer. 202005 16;3(1):15-16. https://doi.org/10.31557/ apjec.2020.3.1.15-16

5. Zhu N, Zhang D, Wang W, Li X, Yang B, Song J, Zhao X, Huang B, Shi W, Lu R, Niu P, Zhan F, Ma X, Wang D, $\mathrm{Xu}$ W, Wu G, Gao GF, Tan W. A Novel Coronavirus from Patients with Pneumonia in China, 2019. New England Journal of Medicine. 202002 20;382(8):727-733. https:// doi.org/10.1056/nejmoa2001017

6. Corman VM, Landt O, Kaiser M, Molenkamp R, Meijer A, Chu DK, Bleicker T, Brünink S, Schneider J, Schmidt ML, Mulders DG, Haagmans BL, van der Veer B, van den Brink S, Wijsman L, Goderski G, Romette J, Ellis J, Zambon M, Peiris M, Goossens H, Reusken C, Koopmans MP, Drosten C. Detection of 2019 novel coronavirus $(2019-\mathrm{nCoV})$ by real-time RT-PCR. Eurosurveillance. 202001 23;25(3). https://doi.org/10.2807/1560-7917.es.2020.25.3.2000045

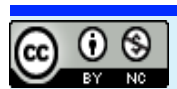

This work is licensed under a Creative Commons AttributionNon Commercial 4.0 International License. 